\title{
Geochemistry and petrogenesis of early Cretaceous sub-alkaline mafic dykes from Swangkre-Rongmil, East Garo Hills, Shillong plateau, northeast India
}

\author{
Rajesh K Srivastava* and Anup K Sinha \\ Igneous Petrology Laboratory, Department of Geology, Banaras Hindu University, Varanasi 221 005, India. \\ *e-mail: rajeshgeolbhu@yahoo.com
}

\begin{abstract}
Numerous early Cretaceous mafic and alkaline dykes, mostly trending in N-S direction, are emplaced in the Archaean gneissic complex of the Shillong plateau, northeastern India. These dykes are spatially associated with the N-S trending deep-seated Nongchram fault and well exposed around the Swangkre-Rongmil region. The petrological and geochemical characteristics of mafic dykes from this area are presented. These mafic dykes show very sharp contact with the host rocks and do not show any signature of assimilation with them. Petrographically these mafic dykes vary from fine-grained basalt (samples from the dyke margin) to medium-grained dolerite (samples from the middle of the dyke) having very similar chemical compositions, which may be classified as basaltic-andesite/andesite. The geochemical characteristics of these mafic dykes suggest that these are genetically related to each other and probably derived from the same parental magma. Although, the high-field strength element (+rare-earth elements) compositions disallow the possibility of any crustal involvement in the genesis of these rocks, but $\mathrm{Nb} / \mathrm{La}, \mathrm{La} / \mathrm{Ta}$, and $\mathrm{Ba} /$ Ta ratios, and similarities of geochemical characteristics of present samples with the Elan Bank basalts and Rajmahal (Group II) mafic dyke samples, suggest minor contamination by assimilation with a small amount of upper crustal material. Chemistry, particularly REE, hints at an alkaline basaltic nature of melt. Trace element modelling suggests that the melt responsible for these mafic dykes had undergone extreme differentiation $(\sim 50 \%)$ before its emplacement. The basaltic-andesite nature of these rocks may be attributed to this differentiation. Chemistry of these rocks also indicates $\sim 10-15 \%$ melting of the mantle source. The mafic dyke samples of the present investigation show very close geochemical similarities with the mafic rocks derived from the Kerguelen mantle plume. Perhaps the Swangkre-Rongmil mafic dykes are also derived from the Kerguelen mantle plume.
\end{abstract}

\section{Introduction}

Dykes occur in a variety of geologic and tectonic settings and their detailed study in space and time helps in various ways to understand several geological events. Dykes are thought to be an integral part of continental rifting and occur in spatially extensive swarms of adequate size that help in correlating of continental fragments. Dykes also serve as major conduits for magma transfer from mantle to the upper crust and constitute a common expression of crustal extension. Another important point is that the continental flood basalts and major dyke swarms have their origin related in some way to the up-rise of hot mantle plumes that ultimately may lead to rifting and, ultimately, continental break-up (Morgan 1971; Fahrig 1987; LeCheminant and Heaman 1989; Oliveira et al 1990). The basic (mafic) nature of dykes is very common and the study of mafic dyke swarms is an important tool in

Keywords. Swangkre-Rongmil; Shillong plateau; mafic dykes; basaltic-andesite; Kerguelen plume; geochemistry; petrogenesis. 

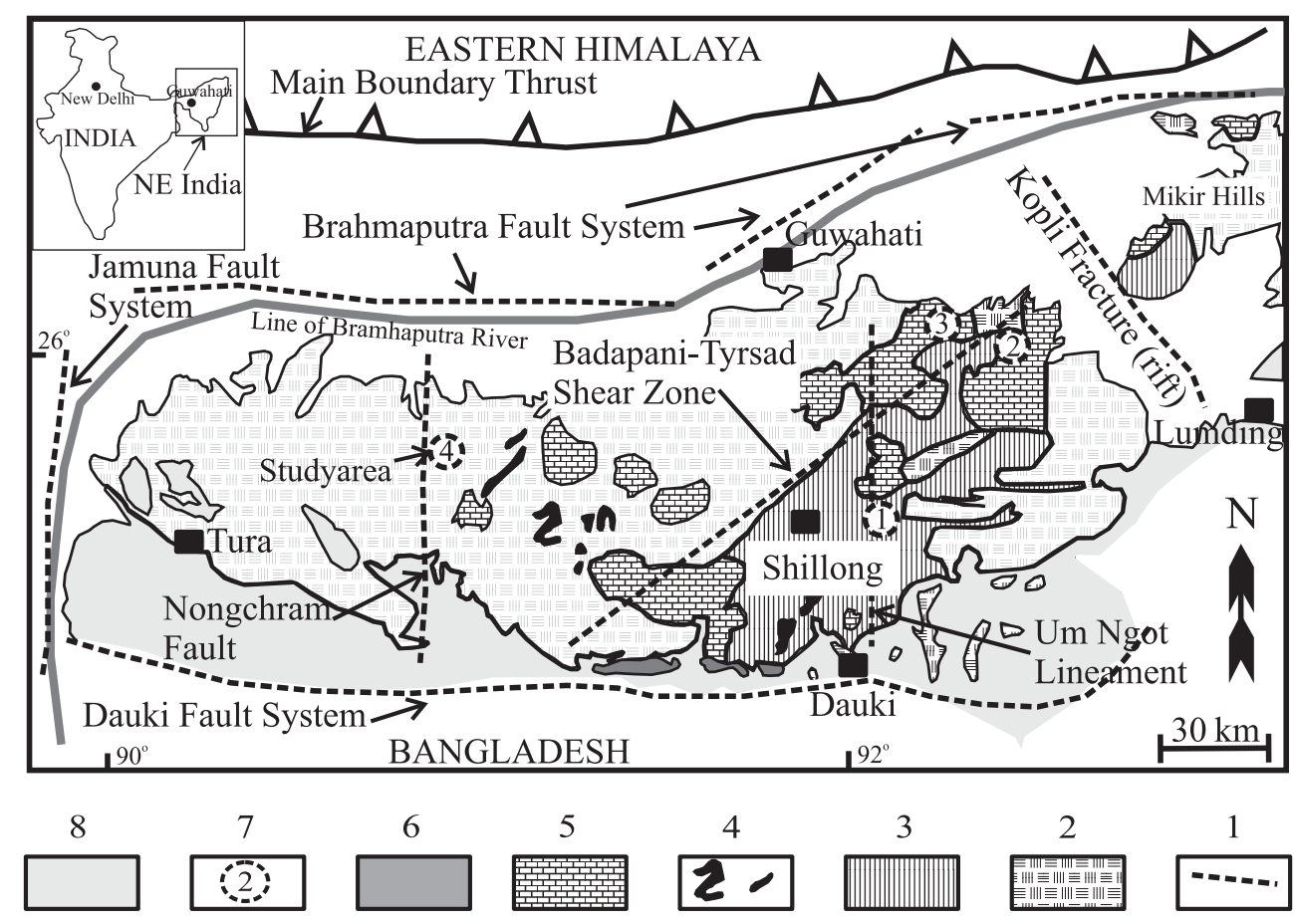

Figure 1. Regional geological and tectonic framework of the Shillong plateau (compiled from Evans 1964; Desikachar 1974; Mazumdar 1976; Nandy 1980; Acharyya et al 1986; Gupta and Sen 1988; Golani 1991; Das Gupta and Biswas 2000). (1) Major fault-systems, (2) Archaean gneissic complex, (3) Shillong Group rocks, (4) Mafic igneous rocks, (5) Porphyritic granites, (6) Sylhet traps, (7) Ultramafic-alkaline-carbonatite complexes. (Circled numbers indicate different locations: (1) Sung valley, (2) Jasra, (3) Samchampi, (4) Swangkre, (8) Cretaceous-Tertiary sediments. Blank portion represents alluvium and recent sediments.)

understanding the evolution of the sub-continental lithosphere (Tarney 1992). The Indian Shield is also full of mafic dyke swarms, having different orientations, and is emplaced in almost all the Archaean cratons (Murthy 1987).

The Shillong plateau also comprises dykes of different petrological nature. These dykes are well exposed around western part of the plateau. This dyke swarm is known as Swangkre dyke swarm and consists of a variety of alkaline and mafic dykes. Most previous workers (Sunilkumar et al 1984; Nambiar and Golani 1985; Nambiar 1987, 1988) have given their attention to examine the alkaline or carbonatite dykes only and no petrological and geochemical work is available on these basic dykes. First hand petrological and geochemical information on mafic dykes of the SwangkreRongmil area, and a suggestion on their possible origin have been presented in the present paper. The detailed petrological and geochemical studies of these dykes are important because most of these follow the direction of major structural features, particularly the deep faults present in the region. Space and time correlation of these dykes with other mafic rocks derived from the Kerguelen mantle plume will help in understanding the continental break-up during the Cretaceous time.

\section{Geological setting}

The mafic dyke swarm under study is emplaced within the Archaean gneissic complex, which includes hornblende and biotite gneisses, porphyritic granitoids and pink granites, of the Shillong plateau (figure 1). The Shillong plateau is considered to be an uplifted horst-like feature, bounded on all sides by several fault systems; namely the E-W Dauki fault in the south, the E-W Brahmaputra fault in the north, the N-S Jamuna fault in the west, and the NW-SE Kopli fracture zone in the east (Evans 1964; Desikachar 1974; Nandy 1980; Acharya et al 1986; Gupta and Sen 1988). Some other deep faults are also reported from the Shillong plateau, which includes:

- N-S trending Nongchram fault (Nambiar and Golani 1985; Nambiar 1988; Gupta and Sen 1988; Golani 1991),

- N-S trending Um Ngot lineaments (Gupta and Sen 1988), and

- NE-SW trending Badapani-Tyrsad shear zone (Kumar et al 1996) (see figure 1).

Gupta and Sen (1988) further stated that most $\mathrm{N}-\mathrm{S}$ trending lineaments are developed during the Late Jurassic-Early Cretaceous times and are 
spatially and temporally associated to the alkaline, mafic, and carbonatite magmatism of the Shillong plateau; important complexes are Sung Valley, Jasra, Samchampi and Swangkre. The present study area is part of the Swangkre alkalinemafic dyke swarm. Besides Archaean gneisses, the Shillong plateau also comprises the Proterozoic Shillong group of rocks ('orthoquartzite' and phyllite), granite plutons (700-450 Ma; Ghose et al 1994), small bodies of metamorphosed mafic igneous rocks, and the Sylhet traps (a part of the Rajmahal-Sylhet flood basalt province) (Desikachar 1974; Mazumdar 1976; Das Gupta and Biswas 2000). The Rajmahal-Sylhet flood basalt province and ultramafic-alkaline-carbonatite complexes of the Shillong plateau are thought to be associated with the Kerguelen plume (Storey et al 1992; Kent et al 1997, 2002; Ray et al 1999, 2000; Srivastava and Sinha 2004a, b).

The study area extends from south of the Swangkre to north of the Rongmil through Nongchram and Rongjeng, covering about $150 \mathrm{~km}^{2}$ of area (Nambiar 1987, 1988). In the present work, mafic dykes exposed between the Swangkre and Rongmil have been studied (figure 2). Most of the dykes of the study area follow the major fault system of N-S trending Nongchram fault, suggesting their relationship with each other (figure 2; Nambiar and Golani 1985; Gupta and Sen 1988; Golani 1991). Mafic (basic) dykes are mainly basalt and dolerite, whereas alkaline dykes include lamprophyre, ijolite, and tinguaite. A carbonatite dyke is also reported near Swangkre (Nambiar and Golani 1985). The studied mafic dykes are melanocratic and fine to medium grained. Petrography of these mafic dykes is presented in a separate section below. These dykes show very sharp contact with granitoids (figure 3a) and no sign of assimilation is noticed.

Radiometric ages are available for the lamprophyre dykes. Sarkar et al (1996) have dated one lamprophyre dyke by K-Ar method and placed it at $107 \pm 3$ Ma. Recently, Coffin et al (2002) have dated biotite extracted from lamprophyre dykes by Ar-Ar method and precisely estimated the age of these dykes at $114.9 \pm 0.3 \mathrm{Ma}$. Although no age data is available for the mafic dyke of the Swangkre-Rongmil area but their close association with lamprophyre dykes suggests that these two are contemporaneous to each other (Nambiar 1987, 1988). Gupta and Sen (1988) clearly stated that alkaline and basic magmatism of the Shillong Plateau are spatially and temporally associated with the N-S trending structural features developed during the Late Jurassic-Early Cretaceous times. Thus, it may be assumed that the mafic dykes of the present study are probably also emplaced around 107-115 Ma.

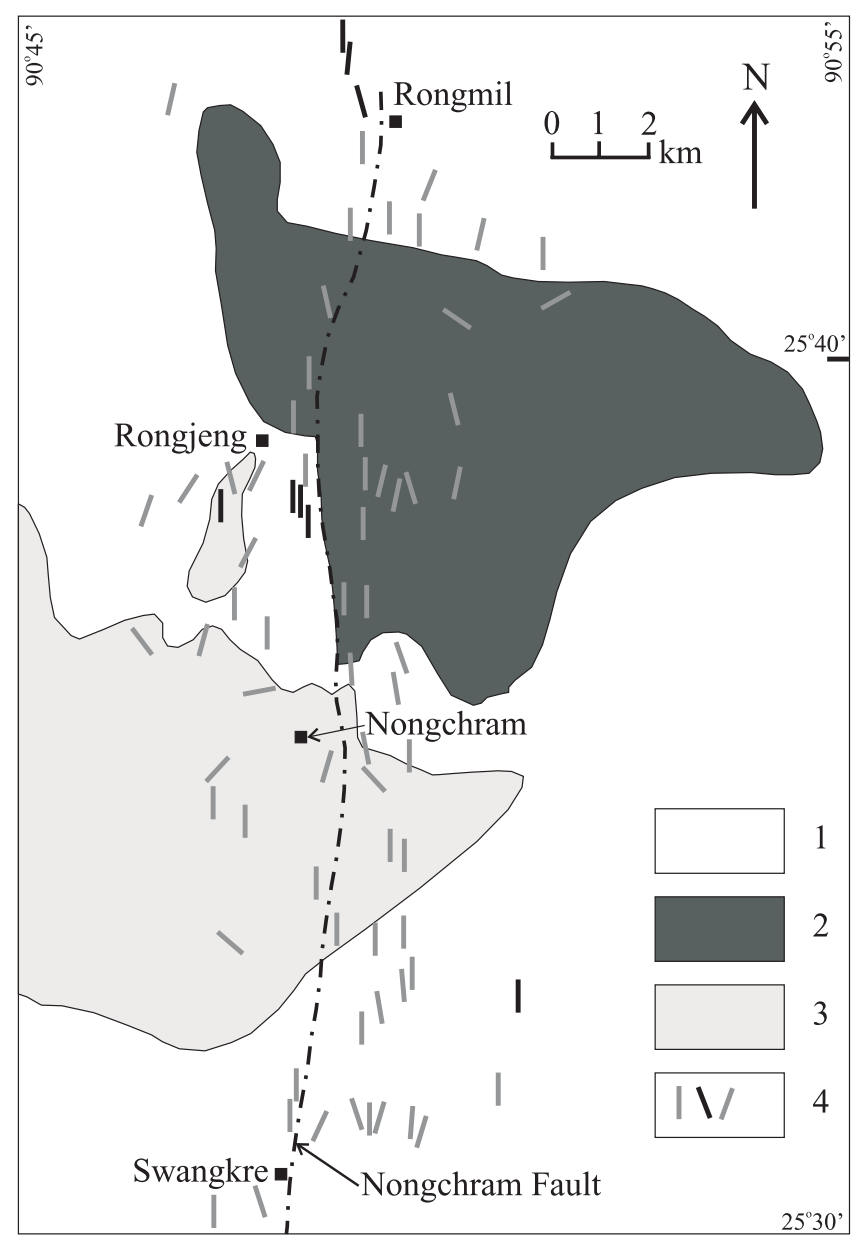

Figure 2. Simplified geological map of Swangkre-Rongmil area (after Nambiar 1987, 1988). (1) Migmatitic gneisses, (2) Porphyritic granite, (3) Pink granite, (4) Dykes of different petrological compositions. Location of studied mafic dykes for the present study are shown by black shades. Width and length of dykes are not to scale.

\section{Petrography}

Under the polarizing microscope most mafic dyke samples are medium-grained; only samples collected from dyke margins are fine-grained (figure $3 \mathrm{~b})$. A variety of textures are seen in these mafic samples but the most common texture is ophitic texture (figure 3c). Sub-ophitic texture is also observed in a number of thin sections. Finegrained variety exhibits intergranular (figure 3b) and intersertal textures. Other important textures observed in few samples are variolitic and open spherulitic (figure 3d). Both these textures are beautifully exhibited by elongated needle-shaped plagioclase grains arranged in fan or radial arrangements respectively. These two textures are probably formed by devitrification of glass. This is further corroborated by the presence of isotropic palagonite grains, which is formed by oxidationhydration of glass. At places porphyritic texture 
is also reported; common phenocryst is plagioclase feldspar.

The major mineral composition of these rocks are plagioclase feldspar and clino-pyroxene. 'An' contents of plagioclase feldspars vary between 5 and 28, hence recognized as albite or oligoclase. Few grains of calcic plagioclases (labradorite) are also reported. Augite is common clino-pyroxene
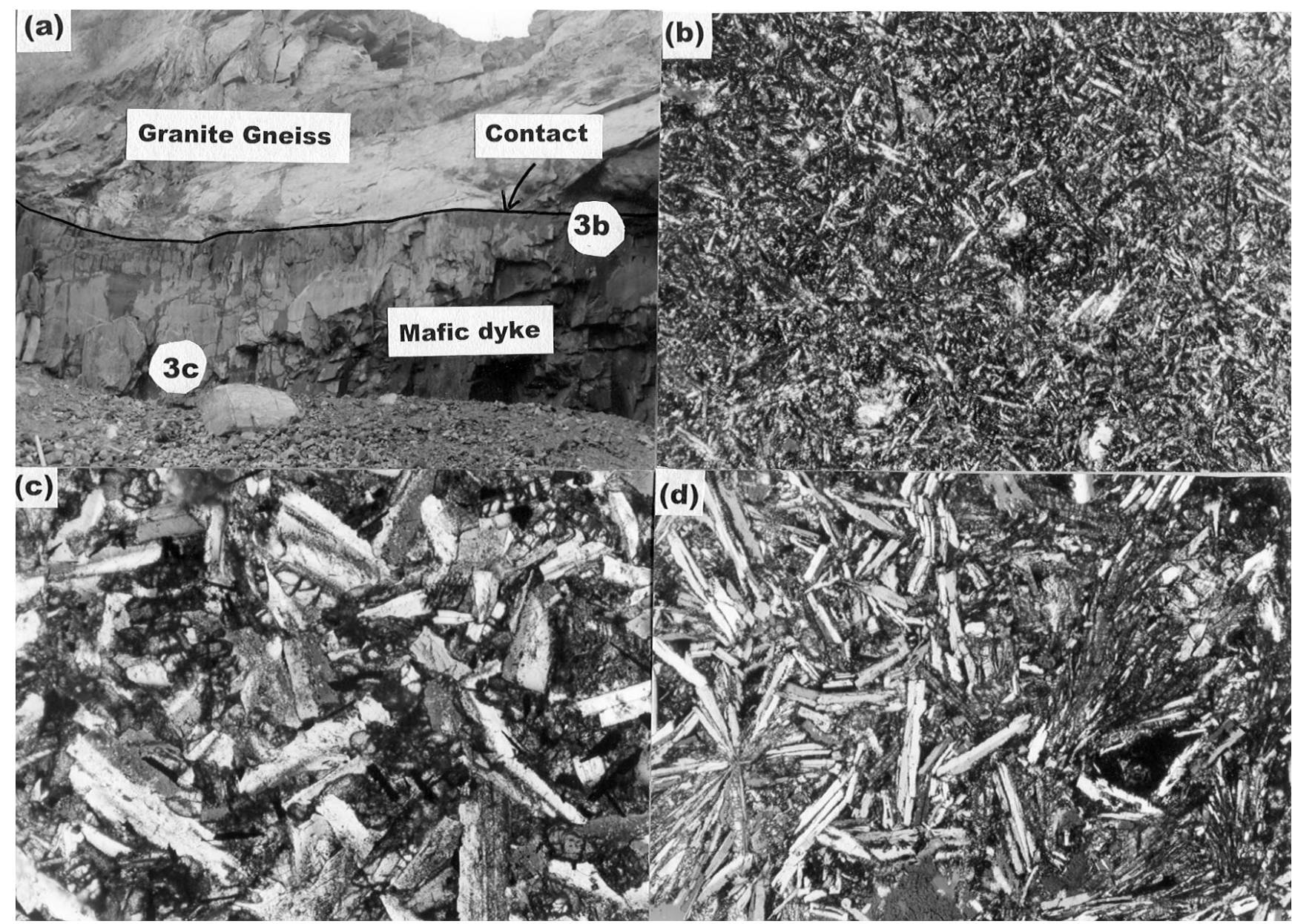

Figure 3. (a) Field-photograph showing sharp contact between mafic dyke and granite gneiss; dyke margin is fine-grained (see figure 3b) and middle portion is medium-grained (see figure 3c); location: Rongmil. (b) Photomicrograph of dyke margin sample; fine-grained and shows intergranular texture. (c) Photomicrograph of middle portion sample; medium-grained and shows ophitic texture. (d) Photomicrograph showing open spherulitic (left side) and variolitic (right side) textures; location: Swangkre. Width of all photomicrographs is equal to $3.1 \mathrm{~mm}$.

Table 1. Comparison of the certified data (C) with the data obtained by the Activation Laboratories Ltd. (A) of used geostandrads.

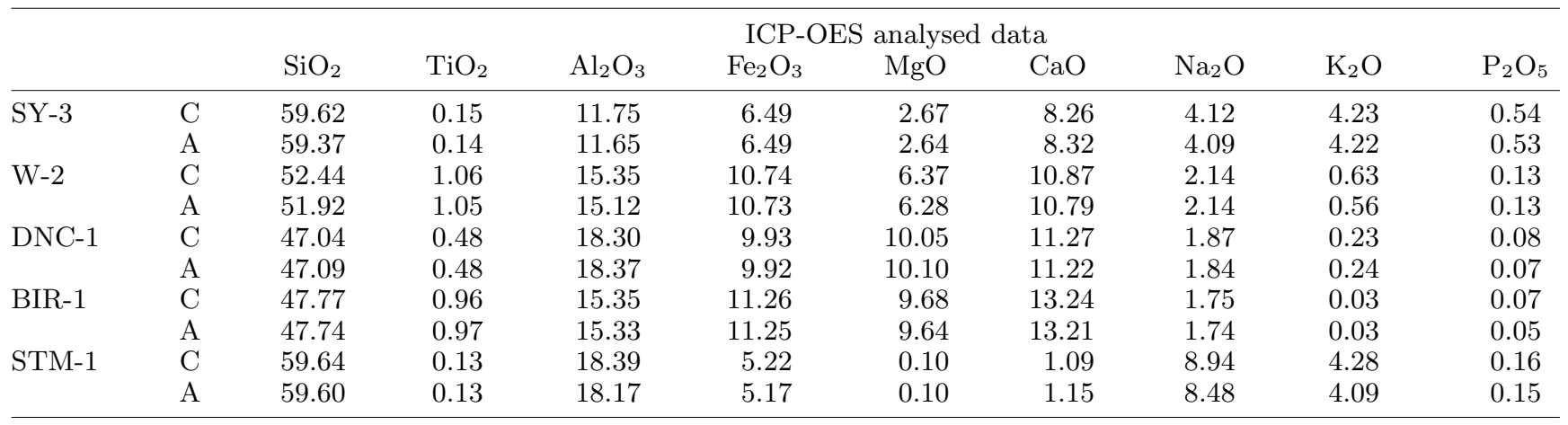

SY-3 (Syenite); W-2 (Diabase); DNC-1 (Dolerite); BIR-1 (Basalt); STM-1 (Syenite). 
present in these samples but few diopside grains are also noticed. Other minerals present in a minor amount (as accessory or secondary constituents) are ilmenite, magnetite, apatite, zircon, palagonite, calcite, and quartz.

\section{Analytical techniques}

Whole rock major and trace element analyses were done at the Activation Laboratories Ltd., Ancaster, Ontario, Canada. ICP-OES (Model: Thermo-JarretAsh ENVIRO II) was used to analyse major elements, whereas ICP-MS (Model: Perkin Elmer Sciex ELAN 6000) was used to determine trace and rare-earth element concentrations. The precision is $<5 \%$ for all analysed elements when reported at $100 \times$ detection limit. Several standards, such as SY-3, W-2, DNC-1, BIR-1 and STM-1, were run along with the SwangkreRongmil samples to check accuracy and precision (see table 1 for detail). Whole rock chemical data of the studied mafic dyke samples is presented in table 2. Table 2 also presents CIPW normative compositions of these rocks. Locations of studied dykes are marked on the geological map (see black shaded dykes in figure 2). Standardised CIPW norms, rock-types, and $\mathrm{Mg} \#$ for all samples were automatically computed using the SINCLAS Computer Programme (Verma et al 2002). Iron-ratio used for CIPW norm calculation is taken from Middlemost (1989).

\section{Geochemistry}

Chemical compositions of studied dyke samples show high-silica high-alumina nature and are quartz-hypersthene normative (table 2). This simply classifies them as quartz tholeiites (Thompson 1984). On total alkali and silica classificatory diagram (TAS, figure 4(a); LeMaitre 2002; dotted line divides sub-alkaline rocks from alkaline rocks is taken from Irvine and Baragar 1971) these samples show sub-alkaline basaltic andesite characteristics, which are further corroborated on the Winchester and Floyd's (1977) $\mathrm{SiO}_{2}-\mathrm{Zr} / \mathrm{TiO}_{2}$ classificatory diagram (figure $4 \mathrm{~b}$ ). SINCLAS computer programme (Verma et al 2002) also confirms their basaltic andesitic nature.

In order to observe the crystallization behaviour of the Swangkre-Rongmil mafic dykes, major oxides are plotted against Zr (figure 5). All plots show a good crystallization trend. With differentiation (i.e., with increasing $\mathrm{Zr}$ ) silica, $\mathrm{P}_{2} \mathrm{O}_{5}$, alkalies, and titanium increase and $\mathrm{MgO}$ and $\mathrm{Al}_{2} \mathrm{O}_{3}$ decrease, suggesting plagioclase and pyroxene fractionation during the evolution of magma. This is well supported by their petrography; more evolved samples contain higher concentration of quartz, opaques, zircon, etc. than the less evolved samples. Similar crystallization behaviour is also observed from $\mathrm{Zr}$ and trace element plots (figure 6); except $\mathrm{Cr}$, all plotted elements (Ba, Sc, Y, Ce, and Nd) increase with increasing $\mathrm{Zr}$. Cr content decreases with differentiation. From these two variation diagrams it might be concluded that:

- the studied samples are probably genetically related to each other through a simple differentiation process and might be derived from same parental magma, and

- a gap exists on the differentiation trends.

These observations are further checked on the primordial-mantle normalized multi-element and chondrite-normalized rare-earth element patterns (figure 7). All plotted elements show enrichment in comparison to normalizing values of primordial mantle and chondrite. A very limited variation is noted from the patterns, particularly high-field strength elements (HFSE) show very similar multi element patterns (figure 7a). Slight variation is due to simple differentiation process, more evolved samples have comparatively higher concentration of HFSE than other samples. This feature is also corroborated on rare-earth element patterns (figure $7 \mathrm{~b}$ ). All samples show an inclined REE pattern,

Table 1. (Continued)

\begin{tabular}{|c|c|c|c|c|c|c|c|c|c|c|c|}
\hline \multirow[b]{2}{*}{$\mathrm{Ba}$} & \multirow[b]{2}{*}{$\mathrm{Sr}$} & \multirow[b]{2}{*}{$\mathrm{Zr}$} & \multirow[b]{2}{*}{$\mathrm{V}$} & \multirow[b]{2}{*}{$\mathrm{Cr}$} & \multirow[b]{2}{*}{$\mathrm{Rb}$} & \multicolumn{4}{|c|}{ ICP-MS analysed data } & \multirow[b]{2}{*}{$\mathrm{Lu}$} & \multirow[b]{2}{*}{ Th } \\
\hline & & & & & & $\mathrm{Ce}$ & $\mathrm{Nd}$ & $\mathrm{Sm}$ & $\mathrm{Eu}$ & & \\
\hline 450 & 302 & 320 & 50 & & & & & & & & \\
\hline 451 & 311 & 333 & 50 & & & & & & & & \\
\hline 182 & 194 & 94 & 262 & 93 & 20 & 24.0 & 14.0 & 3.25 & 1.10 & 0.33 & 2.2 \\
\hline 177 & 193 & 87 & 263 & 86 & 20 & 23.4 & 12.5 & 3.20 & 1.12 & 0.31 & 2.3 \\
\hline 114 & 145 & 41 & 148 & 285 & 145 & 10.6 & 4.9 & 1.38 & 0.59 & 0.32 & 0.2 \\
\hline 106 & 143 & 36 & 139 & 274 & 141 & 8.4 & 5.0 & 1.40 & 0.61 & 0.31 & 0.2 \\
\hline 7.7 & 108 & 22 & 313 & 382 & & 1.95 & 2.5 & 1.1 & 0.54 & 0.26 & \\
\hline 8.0 & 109 & 18 & 322 & 388 & & 2.10 & 2.5 & 1.2 & 0.58 & 0.27 & \\
\hline 560 & 700 & 1210 & & & & & & & & & \\
\hline 595 & 700 & 1205 & & & & & & & & & \\
\hline
\end{tabular}


Table 2. Major (wt\% oxides), trace and rare-earth (ppm) element analyses of basaltic andesites from Rongjeng, East Garo Hills, Meghalaya.

\begin{tabular}{|c|c|c|c|c|c|c|c|c|c|c|}
\hline & 2 & 4 & 10 & 15 & 20 & 21 & 23 & 24 & 27 & 28 \\
\hline $\mathrm{SiO}_{2}$ & 53.27 & 52.35 & 53.57 & 53.36 & 51.85 & 52.16 & 52.85 & 54.75 & 55.13 & 55.22 \\
\hline $\mathrm{TiO}_{2}$ & 1.23 & 1.19 & 1.24 & 1.33 & 1.37 & 1.32 & 1.76 & 1.86 & 1.81 & 1.86 \\
\hline $\mathrm{Al}_{2} \mathrm{O}_{3}$ & 14.95 & 15.33 & 15.47 & 14.98 & 16.42 & 14.75 & 14.24 & 13.63 & 13.85 & 13.94 \\
\hline $\mathrm{Fe}_{2} \mathrm{O}_{3}$ & 10.67 & 9.59 & 9.89 & 9.86 & 9.69 & 9.58 & 13.03 & 10.93 & 11.62 & 10.95 \\
\hline $\mathrm{MnO}$ & 0.14 & 0.12 & 0.12 & 0.13 & 0.07 & 0.07 & 0.16 & 0.15 & 0.15 & 0.15 \\
\hline $\mathrm{MgO}$ & 5.12 & 5.65 & 5.54 & 5.47 & 3.59 & 5.50 & 3.92 & 3.75 & 4.13 & 3.83 \\
\hline $\mathrm{CaO}$ & 7.47 & 6.32 & 6.96 & 7.68 & 6.23 & 6.39 & 6.21 & 6.99 & 6.95 & 6.98 \\
\hline $\mathrm{Na}_{2} \mathrm{O}$ & 2.71 & 3.60 & 3.17 & 2.76 & 3.24 & 2.84 & 3.01 & 2.92 & 3.01 & 2.92 \\
\hline $\mathrm{K}_{2} \mathrm{O}$ & 0.58 & 1.06 & 1.13 & 1.14 & 0.88 & 0.98 & 1.35 & 1.53 & 1.48 & 1.55 \\
\hline $\mathrm{P}_{2} \mathrm{O}_{5}$ & 0.18 & 0.17 & 0.19 & 0.21 & 0.20 & 0.19 & 0.35 & 0.35 & 0.36 & 0.35 \\
\hline LOI & 3.68 & 4.39 & 2.65 & 2.39 & 6.01 & 5.11 & 3.33 & 2.17 & 1.48 & 2.28 \\
\hline Total & 100.00 & 99.67 & 99.53 & 99.31 & 99.55 & 98.89 & 100.20 & 99.03 & 99.97 & 100.03 \\
\hline $\mathrm{Mg} \#$ & 54.69 & 59.71 & 58.49 & 58.26 & 48.25 & 59.09 & 43.08 & 47.19 & 47.21 & 46.81 \\
\hline $\mathrm{Cr}$ & & & 70 & 58 & 67 & & 50 & & 44 & \\
\hline $\mathrm{Ni}$ & & & 32 & 34 & 31 & & 39 & & 40 & \\
\hline $\mathrm{Sc}$ & 20 & 19 & 20 & 20 & 22 & 21 & 24 & 23 & 24 & 24 \\
\hline V & 152 & 153 & 256 & 162 & 172 & 160 & 179 & 170 & 171 & 170 \\
\hline $\mathrm{Rb}$ & & & 32 & 26 & 27 & & 27 & & 28 & \\
\hline $\mathrm{Ba}$ & 485 & 281 & 340 & 302 & 291 & 277 & 446 & 525 & 532 & 511 \\
\hline $\mathrm{Sr}$ & 322 & 353 & 347 & 312 & 300 & 277 & 285 & 364 & 334 & 353 \\
\hline $\mathrm{Ga}$ & & & 21 & 21 & 22 & & 23 & & 22 & \\
\hline $\mathrm{Ta}$ & & & 0.5 & 0.4 & 0.4 & & 0.5 & & 0.6 & \\
\hline $\mathrm{Nb}$ & & & 18 & 14 & 12 & & 13 & & 13 & \\
\hline Hf & & & 3.2 & 3.7 & 3.7 & & 4.7 & & 4.8 & \\
\hline $\mathrm{Zr}$ & 116 & 110 & 110 & 133 & 125 & 120 & 161 & 176 & 170 & 183 \\
\hline Y & 27 & 26 & 27 & 31 & 30 & 28 & 37 & 40 & 38 & 40 \\
\hline $\mathrm{Th}$ & & & 3.2 & 2.9 & 3.5 & & 1.5 & & 1.6 & \\
\hline $\mathrm{U}$ & & & 0.3 & 0.3 & 0.3 & & 0.3 & & 0.3 & \\
\hline $\mathrm{La}$ & & & 16.70 & 19.50 & 18.80 & & 21.70 & & 22.60 & \\
\hline $\mathrm{Ce}$ & & & 35.80 & 41.30 & 39.50 & & 47.30 & & 49.10 & \\
\hline $\operatorname{Pr}$ & & & 4.09 & 4.72 & 4.54 & & 5.78 & & 5.96 & \\
\hline $\mathrm{Nd}$ & & & 18.10 & 20.60 & 19.50 & & 25.90 & & 27.30 & \\
\hline $\mathrm{Sm}$ & & & 4.60 & 5.20 & 4.90 & & 6.70 & & 6.80 & \\
\hline $\mathrm{Eu}$ & & & 1.59 & 1.79 & 1.72 & & 2.18 & & 2.29 & \\
\hline $\mathrm{Gd}$ & & & 5.70 & 6.40 & 5.90 & & 8.00 & & 8.20 & \\
\hline $\mathrm{Tb}$ & & & 1.00 & 1.10 & 1.00 & & 1.30 & & 1.40 & \\
\hline Dy & & & 5.40 & 6.10 & 5.80 & & 7.50 & & 7.70 & \\
\hline Ho & & & 1.10 & 1.20 & 1.20 & & 1.50 & & 1.50 & \\
\hline Er & & & 3.10 & 3.50 & 3.50 & & 4.20 & & 4.40 & \\
\hline $\mathrm{Tm}$ & & & 0.44 & 0.50 & 0.50 & & 0.60 & & 0.63 & \\
\hline $\mathrm{Yb}$ & & & 2.66 & 2.90 & 3.00 & & 3.60 & & 3.70 & \\
\hline $\mathrm{Lu}$ & & & 0.40 & 0.45 & 0.42 & & 0.55 & & 0.55 & \\
\hline \multicolumn{11}{|c|}{ CIPW Norms } \\
\hline $\mathrm{Q}$ & 9.88 & 3.61 & 6.01 & 7.56 & 8.54 & 8.41 & 8.42 & 11.56 & 10.08 & 11.22 \\
\hline Or & 3.59 & 6.62 & 6.92 & 7.01 & 5.60 & 6.22 & 8.32 & 9.41 & 8.97 & 9.46 \\
\hline $\mathrm{Ab}$ & 24.01 & 32.19 & 27.80 & 24.29 & 29.55 & 25.83 & 26.57 & 25.73 & 26.10 & 25.50 \\
\hline An & 28.19 & 23.82 & 25.53 & 26.12 & 29.82 & 26.45 & 22.28 & 20.37 & 20.40 & 21.00 \\
\hline Di & 7.72 & 6.64 & 7.31 & 9.87 & 1.72 & 5.13 & 6.23 & 11.03 & 10.37 & 10.24 \\
\hline Hy & 20.28 & 21.20 & 20.37 & 18.86 & 18.24 & 21.61 & 19.66 & 13.42 & 16.03 & 14.61 \\
\hline Mt & 3.44 & 3.12 & 3.16 & 3.16 & 3.22 & 3.17 & 4.19 & 3.95 & 3.67 & 3.48 \\
\hline Il & 2.45 & 2.39 & 2.44 & 2.63 & 2.81 & 2.70 & 3.49 & 3.68 & 3.52 & 3.65 \\
\hline Ap & 0.44 & 0.42 & 0.46 & 0.51 & 0.50 & 0.47 & 0.85 & 0.84 & 0.86 & 0.84 \\
\hline
\end{tabular}

$\mathrm{La}^{\mathrm{N}} / \mathrm{Lu}^{\mathrm{N}}$ ratio is more than 5 (see inset plot of figure $7 \mathrm{~b}$ ). These patterns also suggest that the studied samples are genetically related to each other. The gap existing on the differentiation trends shown on the variation diagram is simply due to non-availability of samples of this composition.
REE patterns of the Swangkre-Rongmil mafic dyke samples also suggest their association to the alkali basalt group $\left(\mathrm{Na}_{2} \mathrm{O}>\mathrm{K}_{2} \mathrm{O} ; \mathrm{K}_{2} \mathrm{O}+\mathrm{Na}_{2} \mathrm{O} \approx 3.4\right.$; Cullers and Graf 1984). Mafic rocks belonging to this group exhibits inclined REE patterns and do not show $\mathrm{Eu}$ anomaly $\left(\mathrm{La}^{\mathrm{N}} / \mathrm{Lu}^{\mathrm{N}}=3.6-34\right.$; 

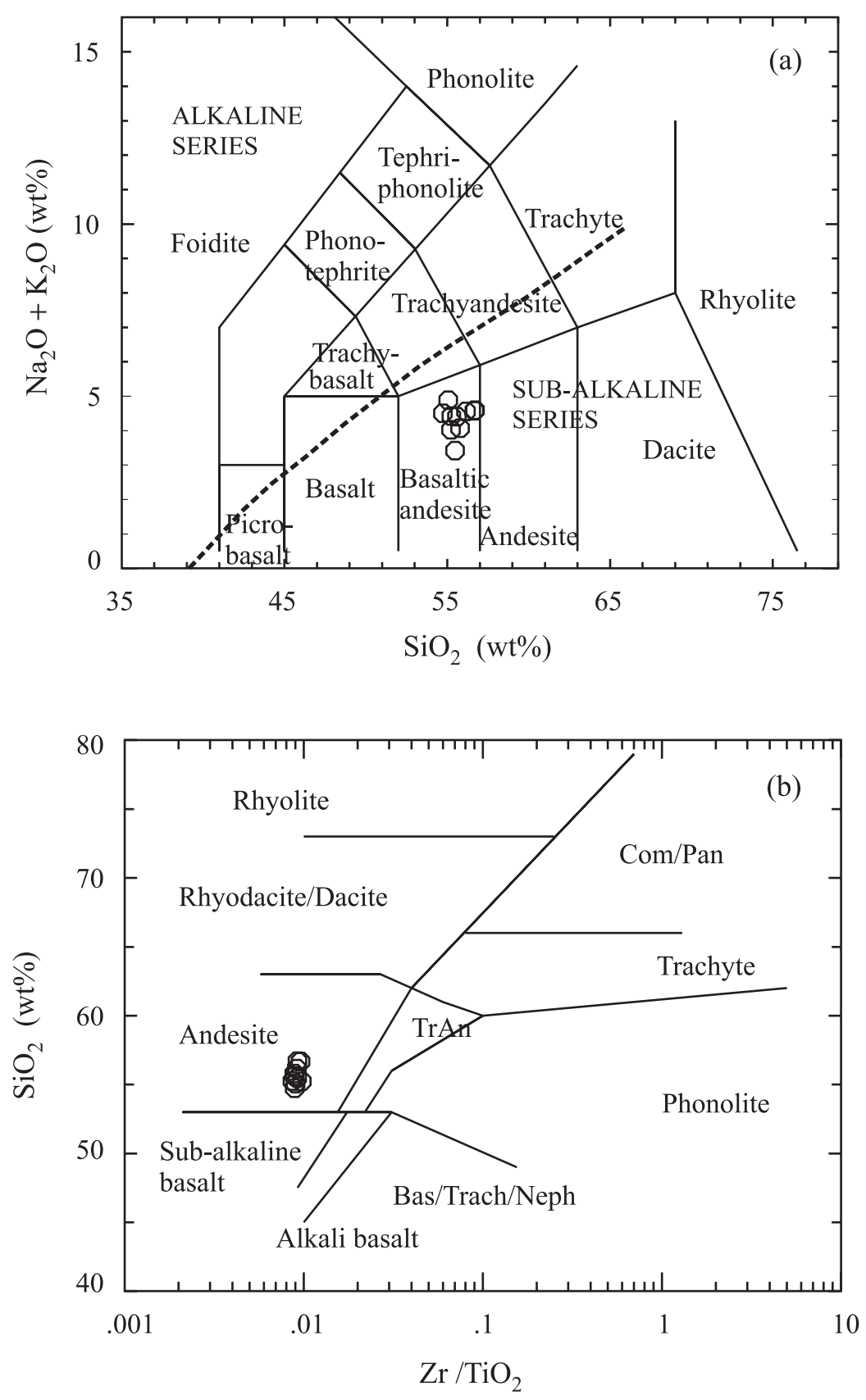

Figure 4. (a) Total-alkali and silica (TAS) diagram (after Le Maitre 2002). Dotted line divides sub-alkaline rocks from alkaline rocks (after Irvine and Baragar 1971). (b) Chemical classification scheme after Winchester and Floyd (1977). The data plotted in these diagrams were adjusted on $100 \%$ anhydrous basis.

see table 7.1 of Cullers and Graf 1984). This observation suggests that melt responsible for the genesis of studied samples was probably having alkaline basaltic nature but due to extreme differentiation, before its emplacement, the studied samples show basaltic andesitic characteristic. Existence of alkaline magmatism in the Shillong plateau (Kumar et al 1996) also supports this view.

It is difficult to establish the role of crustal contamination during the emplacement of magma on the basis of available geochemical data but exist- ing petrological and geochemical data preclude possibility of contamination by crust. As stated above, no signature of assimilation is noticed on the dyke margins (figure 3a). Chemical composition of dyke margin-sample (23) and middle-portion sample (24) is similar (see table 2). Another important point is that HFSE and REE patterns do not show any contamination signature because contaminated samples should exhibit inconsistent patterns. Samples contaminated by crust should also exhibit steeper slope for LREE than HREE as crustal material are enriched in LREE. In 

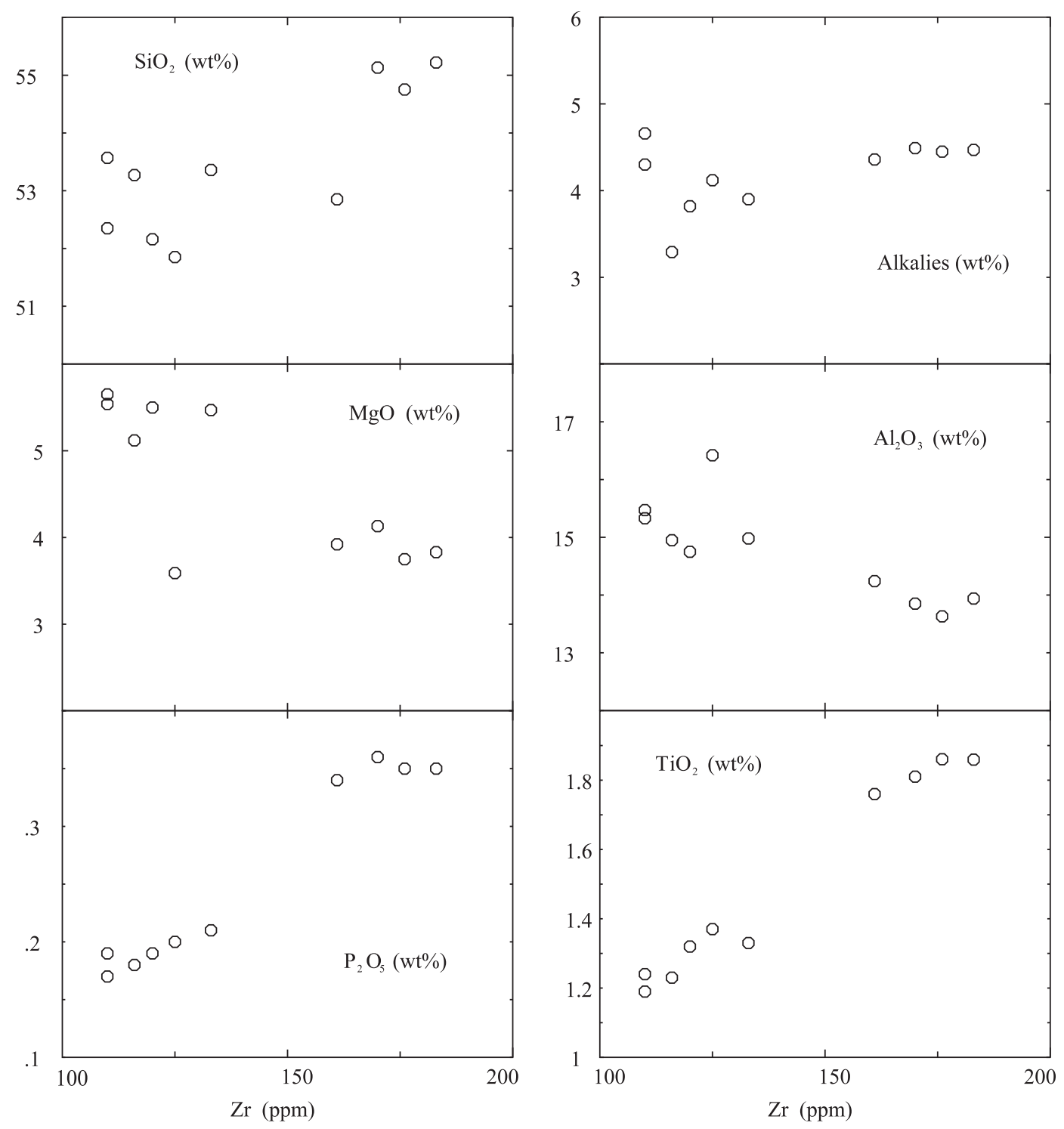

Figure 5. Variation diagram between $\mathrm{Zr}$ and major-minor oxides.

such cases $\mathrm{La}^{\mathrm{N}} / \mathrm{Eu}^{\mathrm{N}}$ ratio should be higher than $\mathrm{Eu}^{\mathrm{N}} / \mathrm{Lu}^{\mathrm{N}}$ but this is not observed in the present case. Even with these explanations it is not simple to rule out the possibility of pre-contamination of mantle source (mantle metasomatism) (Tarney and Weaver 1987). Nb/La ratios in studied samples vary between 0.58 and 1.08 that is very close to $\mathrm{Nb} / \mathrm{La}$ ratio of Primordial Mantle (1.01; McDonough et al 1992) but, on the other hand, it also approaches to $\mathrm{Nb} / \mathrm{La}$ ratio of Lower Crust (0.23; Weaver and Tarney 1984). Ingle et al (2002) have observed that basalts recovered from the ODP Site 1137 and the Rajmahal tholeiites, both associated with the Kerguelen plume, show geochemical similarities. The present mafic dyke rocks are also compared with basalt of the Site 1137 (Ingle et al 2002) and Group II mafic dykes of the Rajmahal area (Kent et al 1997) (figure 8). From fig- ure 8(a) it is observed that HFSE trends of plotted samples show good correlation in comparison to LILE trends. This is because during alteration some incompatible elements (e.g., Rb, K, Ba) are mobile and few other incompatible elements (e.g., Zr, Y, REE) are immobile (Pearce and Cann 1971, 1973; Verma 1992; Jochum and Verma 1996). The geochemical similarities observed between these rocks and plate tectonic reconstructions suggest their association to the Kerguelen plume. Here it is important to mention that Ingle et al (2002) suggested that the magma responsible for basalts of the ODP Site 1137 on the Kerguelen Plateau was contaminated by assimilation of about $7 \%$ of the upper crustal material. Similar inference has also been made for the Group II Rajmahal mafic dykes and basalts (Kent et al 1997). In another diagram (figure 8b), La/Ta and $\mathrm{Ba} / \mathrm{Ta}$ ratios are used for 

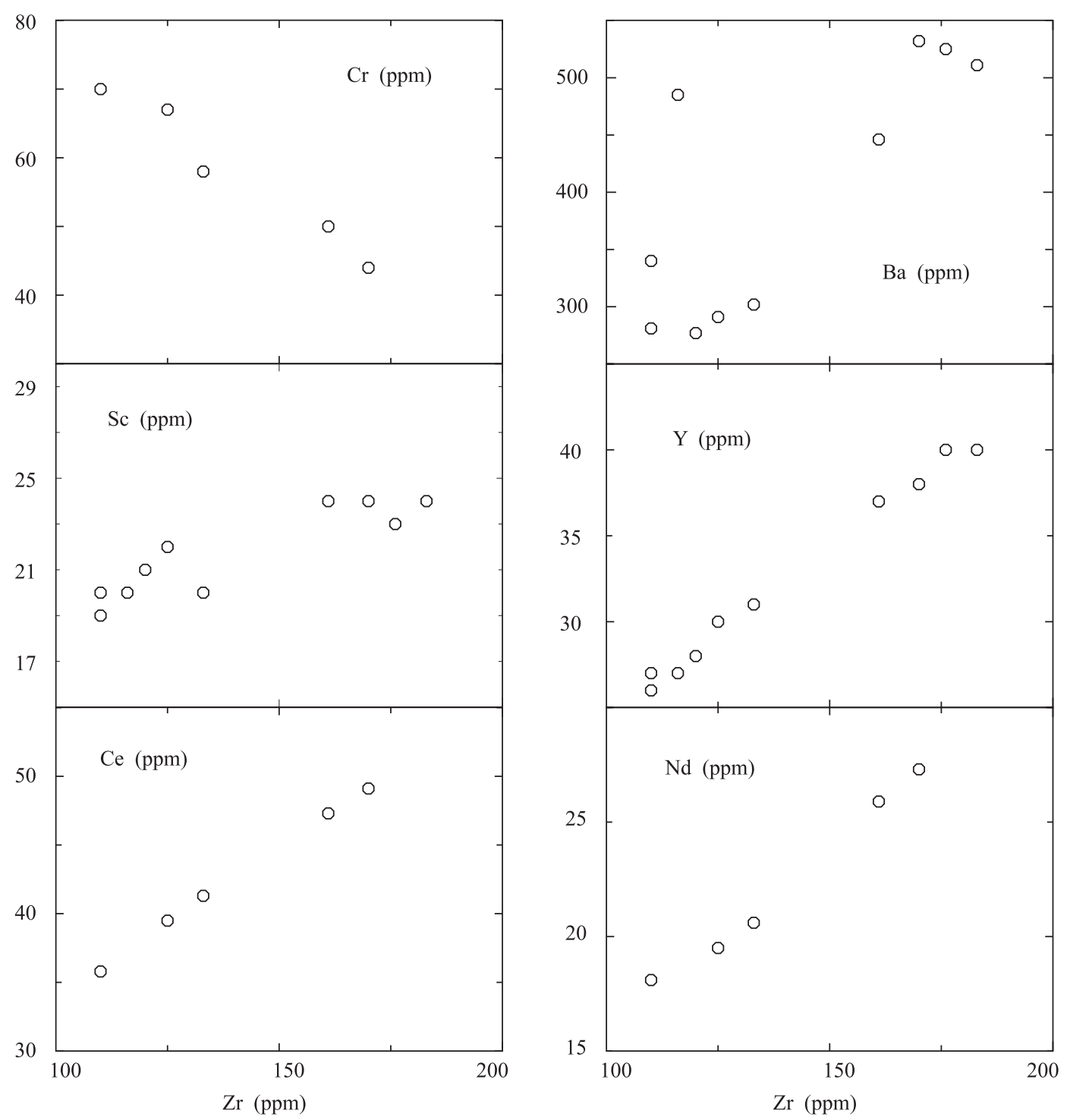

Figure 6. Variation diagram between $\mathrm{Zr}$ and trace elements.

comparison. Studied samples are well comparable with basalts from the Bunbury (Gosselin), Rajmahal (Group II), and Kerguelen plateau. The high $\mathrm{Ba} / \mathrm{Ta}$ ratios observed in these rocks again suggest involvement of crust. Thus, it is believed that the Swangkre-Rongmil dyke samples are probably also derived from a magma contaminated with a minor amount of crustal material, but it requires further chemical data, particularly isotopic data, to prove this hypothesis or otherwise.

\section{Discussion}

From the above presented petrological and geochemical data on the studied samples from the Swangkre-Rongmil area it is supposed that samples are genetically related to each other and associated with the Kerguelen mantle plume. As most samples are basaltic-andesite in character, probably normal basaltic fractionation has occurred prior to emplacement of these mafic dykes. We have limited geochemical data from the study area hence it is difficult to construct any viable genetic model based on this. But we have tested our data on genetic models presented by other authors. For this purpose a crystallization model suggested by Cadman et al (2001) for Kangâmiut dykes (exposed in the W. Greenland) is used for the present samples, and is presented in figure 9. Modelled fractionation crystallization assemblages used for $\mathrm{Zr}$ vs. $\mathrm{TiO}_{2}, \mathrm{Y}$, and $\mathrm{Cr}$ are consistent of a 1:1 ratio of clinopyroxene and plagioclase. Primordial mantle value (McDonough et al 1992) is also presented for comparison. Samples from the present study fall just below the modelled fractionation trends for $\mathrm{Zr}-\mathrm{TiO}_{2}$ and $\mathrm{Zr}-\mathrm{Y}$ (figures $9 \mathrm{a}$ and $9 \mathrm{~b}$ ) but follow very closely the fractionation trends. 


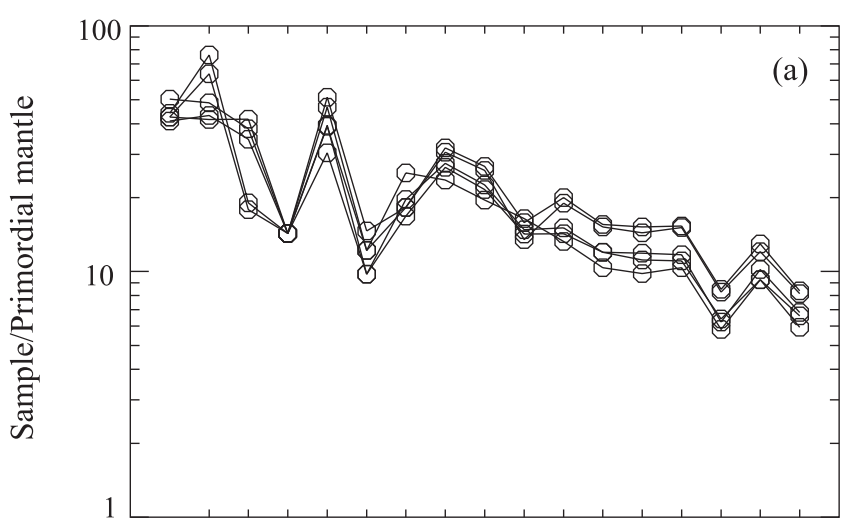

RbBa Th U K Ta NbLa Ce Sr NdHf Zr SmTi Tb Y

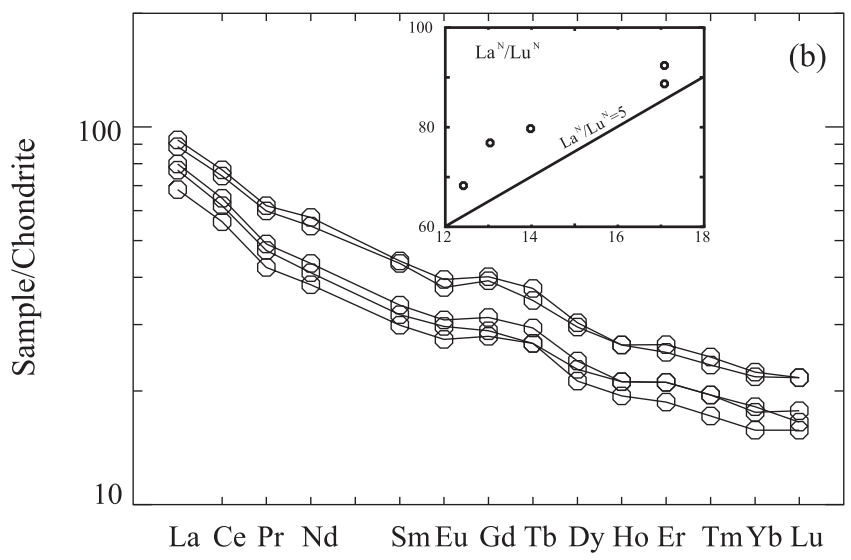

Figure 7. (a) Primordial mantle normalized multi-elements spidergrams. Normalized values are after McDonough et al (1992). (b) Chondite normalized rare-earth patterns. Chondrite values are after Evenson et al (1978). Inset plot shows $\mathrm{La}^{\mathrm{N}} / \mathrm{Lu}^{\mathrm{N}}$ ratio of the studied samples.

On $\mathrm{Zr}$-Cr plot (figure 9c) studied samples follow exactly the same crystallization trend as observed for the Kangâmiut samples. These features probably suggest similar evolutionary/genetic history for these two suites of mafic rocks. Figure $9(\mathrm{~d})$ is prepared to compare presumed primitive sample from the Kangâmiut mafic suite with the present samples. Multi-element trends of the SwangkreRongmil dykes show very close similarities with the trend of primitive sample of Kangâmiut dyke. This also supports the earlier recorded observations but certainly to prove this hypothesis radioactive data is required. On the basis of these plots (figure 9) it is presumed that the Swangkre-Rongmil dykes are product of about 50 to $70 \%$ fractionation of a mantle derived alkaline basaltic magma. Cadman et al (2001) have suggested that incompatible element (HFSE + REE) enrichment within the dykes resulted from subduction-related mantle metasomatism; either may be linked to passage of a slab window underneath the metasomatized region or a mantle plume ascending under subduction zone.

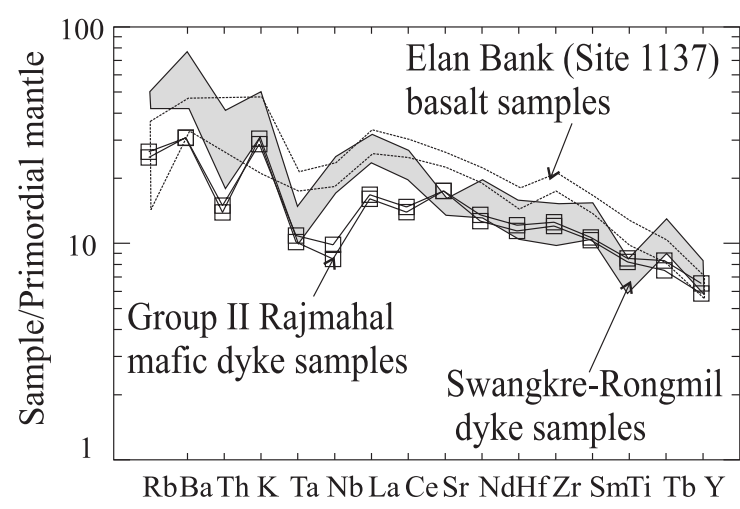

(a)

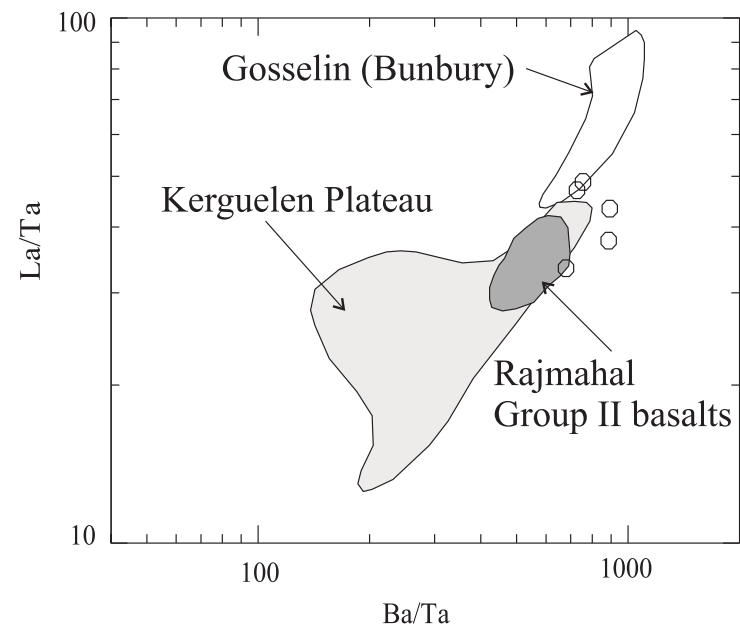

Figure 8. (a) Comparison of geochemical characteristics of present samples with Elan Bank (Site 1137) basalt samples (Ingle et al 2002) and Group II Rajmahal mafic dyke samples (Kent et al 1997). (b) Comparison of $\mathrm{Ba} / \mathrm{Ta}$ and $\mathrm{La} / \mathrm{Ta}$ ratios of Kerguelen plume derived rocks with the Swangkre-Rongmil mafic dyke samples. Data source: Gosselin-type Bunbury basalts (Storey et al 1992; Frey et al 1996), Rajmahal Group II basalts (Kent et al 1997), Kerguelen plateau basalts (Salters et al 1992; Mahoney et al 1995).

We prefer later mechanism for melting of mantle to produce magma for the Swangkre-Rongmil mafic dykes. This is because the Shillong plateau experienced alkaline and mafic magmatism associated to the Kerguelen plume during the Cretaceous time (see table 3 for references). It is also well known that many mid-Proterozoic to Phanerozoic dyke swarms seem ideal candidates for plumeinduced magmatism (LeCheminant and Heaman 1989; Thompson and Gibson 1991; Baragar et al 1996).

Before discussing further the relation of studied samples to the plume magmatism, we present here some more petrogenetic models based on compatible ( $\mathrm{Cr}$ and $\mathrm{Ni}$ ) and incompatible ( $\mathrm{Zr}$ and La) trace elements (figure 10). Such diagrams are successfully used to evaluate melting or differentiation processes of the mantle (Rajamani et al 1985; Condie et al 1987; Knoper and Condie 1988). 

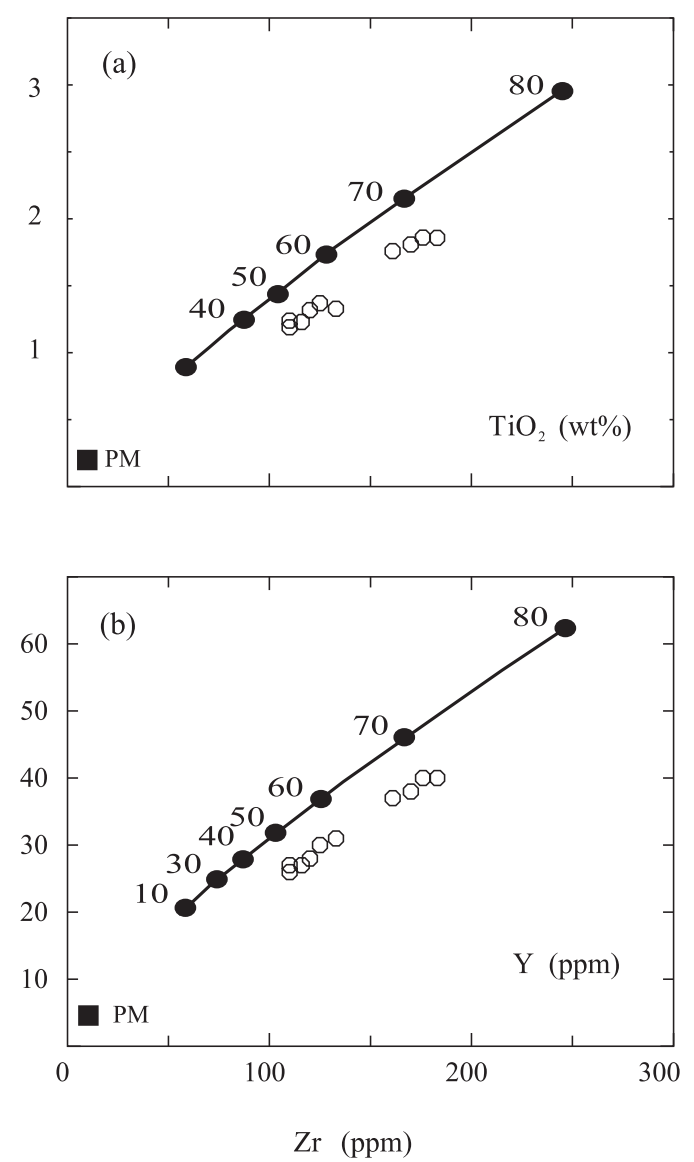
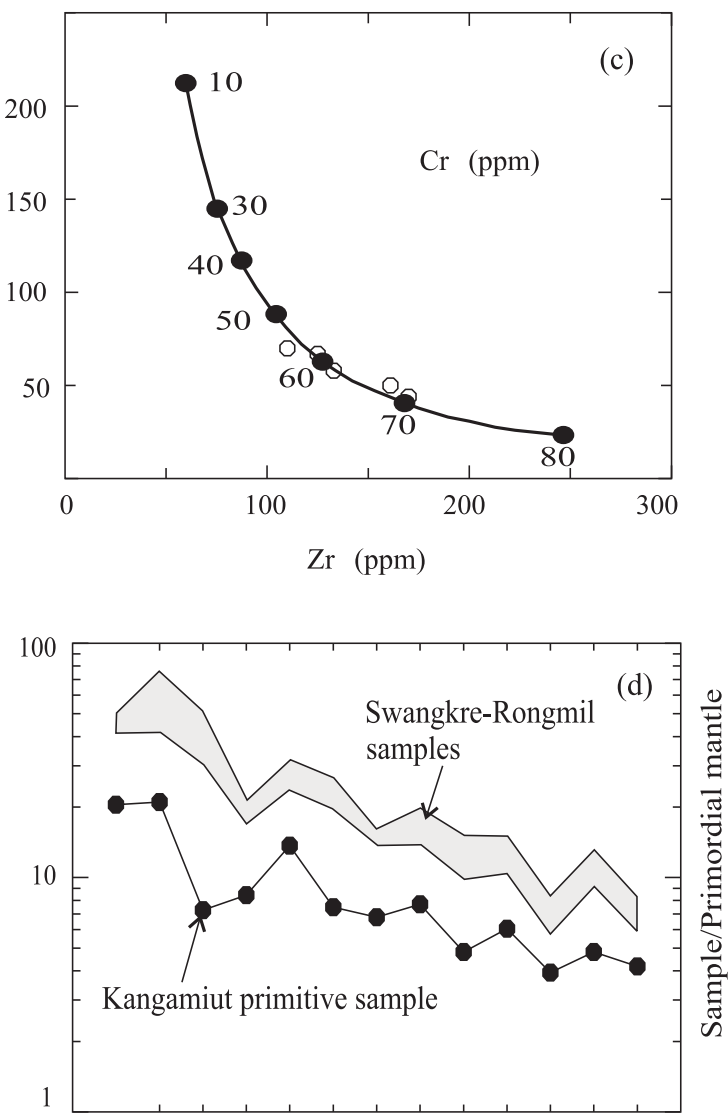

$\mathrm{Rb} \mathrm{Ba} \mathrm{K} \quad \mathrm{Nb} \mathrm{La} \mathrm{Ce} \mathrm{Sr} \mathrm{Nd} \mathrm{Zr} \mathrm{Sm} \mathrm{Ti}$ Tb $\mathrm{Y}$

Figure 9. Biaxial plot showing fractionation trends (after Cadman et al 2001), samples from the present study area are also plotted. (a) $\mathrm{Zr}-\mathrm{TiO}_{2}$ plot, (b) $\mathrm{Zr}-\mathrm{Y}$ plot, and (c) $\mathrm{Zr}-\mathrm{Cr}$ plot. Fractionation trends are derived from supposed primitive sample from the Kangâmiut dyke of W. Greenland. The fractionation crystallization assemblage used consistent of a 1:1 ratio of clinopyroxene and plagioclase. Numbers give amount of fractionation. PM: Primordiam Mantle value (after McDonough et al 1992). (d) Multi-element plot for Swangkre-Rongmil dyke samples (present study) and Kangâmiut primitive sample (Cadman et al 2001) for comparison.

Figure $10(\mathrm{a}$ and $\mathrm{b})$ present variation of $\mathrm{Cr}-\mathrm{Zr}_{\mathrm{N}}$ and $\mathrm{Cr}^{-L a_{N}}$ along with batch melting and fractional crystallisation curves (after Knoper and Condie 1988). Both the plots suggest that the SwangkreRongmil mafic dyke samples are derived from a $\sim 40-50 \%$ fractionated mafic magma; melt generated by $\sim 15 \%$ melting of deep-mantle source. These plots also suggest closed-system fractionation processes. Another model based on Ni-Zr (figure 10c; Condie et al 1987) also corroborates previous observations. This plot suggests that studied rocks can be produced by $\sim 10 \%$ batch melting of a lherzolite source (pyrolite composition with $11 \mathrm{ppm} \mathrm{Zr}$ and $2000 \mathrm{ppm} \mathrm{Ni}$ ), followed by $>50 \%$ fractional crystallisation of olivine. Any melt generated by $\sim 10 \%$ melting of a mantle may show alkaline basaltic nature but due to differentiation of such magma prior to its emplacement, the studied mafic dyke samples show basaltic andesitic nature. These observations are interestingly consistent with observations noticed on the other plots (figures 7 and 9). The cause of melting of deep- seated mantle is probably due to Kerguelen mantle plume.

Fitton et al (1997) and Baksi (2000) have used $\mathrm{Nb}, \mathrm{Y}$, and $\mathrm{Zr}$ to identify plume nature of samples. If $\Delta \mathrm{Nb}(=\log (\mathrm{Nb} / \mathrm{Y})+1.74-1.92 \times \log (\mathrm{Zr} / \mathrm{Y}))$ value of any sample is more than 0 , it may be derived from a plume (Fitton et al 1997). Baksi (2000) has presented this in a diagram (figure 11) in which $\log (\mathrm{Zr} / \mathrm{Y})$ has been plotted against $\log (\mathrm{Nb} / \mathrm{Y})$. Specimens lying between the lines $\log (\mathrm{Nb} / \mathrm{Y})(=1.92 \times \log (\mathrm{Zr} / \mathrm{Y})-1.74)$ and $\log (\mathrm{Nb} / \mathrm{Y})(=1.92 \times \log (\mathrm{Zr} / \mathrm{Y})-1.176)$ are inferred to be plume derived (figure 11; Baksi 2000). All samples from the present study area show plume signature.

Recently, Journal of Petrology has published a special issue on magmatism related to the Kerguelen hotspot (Volume 43, Number 7, 2002) that contains almost a complete information on rocks associated to this plume. Kerguelen plume is responsible for the eruption of basaltic magma in and around Kerguelen plateau, Broken ridge, 
Table 3. Age data on basalts from the Kerguelen plateau, Broken ridge, Naturaliste plateau, Bunbury, and Rajmahal-Sylhet Igneous province, lamprophyres from conjugate Indian and Antarctic margins, and associated ultramafic-alkaline-carbonatite complexes of Shillong plateau.

\begin{tabular}{|c|c|c|c|}
\hline Method & Material & Age (in Ma) & References \\
\hline \multicolumn{4}{|l|}{ Kerguelen plateau } \\
\hline $\mathrm{Ar}-\mathrm{Ar} \quad \mathrm{I}$ & Basalt from ODP site 1136 & $118-119$ & \multirow{4}{*}{ Coffin et al (2002); Duncan (2002) } \\
\hline & Basalt from ODP site 1137 & $107-108$ & \\
\hline & Basalt from ODP sites 749 and 750 & $110-112$ & \\
\hline & Basalt from ODP site 1138 & $\sim 100$ & \\
\hline Broken ridge & & & \\
\hline Ar-Ar & Basalt from ODP sites 1141 and 1142 & $\sim 100$ & Coffin et al (2002); Duncan (2002) \\
\hline \multicolumn{4}{|c|}{ Naturaliste plateau } \\
\hline Ar-Ar $\quad \mathrm{I}$ & Basalt & $100.6 \pm 1.2$ & Pyle et al (1995) \\
\hline Bunbury, western $A$ & Australia & & \\
\hline $\operatorname{Ar}-\mathrm{Ar} \quad \mathrm{I}$ & Basalt lava & $123-130$ & Frey et al (1996); Coffin et al (2002) \\
\hline \multicolumn{4}{|c|}{ Rajmahal-Sylhet Flood Basalts Province } \\
\hline Ar-Ar $\quad \mathrm{E}$ & Basalts & $105-118$ & $\begin{array}{l}\text { Baksi et al (1987); Baksi (1995); } \\
\text { Kent et al }(1997,2002) ; \\
\text { Coffin et al }(2002)\end{array}$ \\
\hline \multicolumn{4}{|c|}{$\begin{array}{l}\text { Ultramafic-alkaline-carbonatite complexes from Shillong plateau } \\
\text { 1. Sung valley }\end{array}$} \\
\hline Ar-Ar $\quad \mathrm{H}$ & $\begin{array}{l}\text { Pyroxenite (WR) and phlogopite from } \\
\text { carbonatite }\end{array}$ & $107.2 \pm 0.8$ & Ray et al (1999) \\
\hline $\mathrm{Rb}-\mathrm{Sr}$ & $\begin{array}{l}\text { Carbonatite (WR), pyroxenite (WR), } \\
\text { and phlogopite from carbonatite }\end{array}$ & $106 \pm 11$ & Ray et al (2000) \\
\hline $\mathrm{U}-\mathrm{Pb}$ & Perovskite from ijolite & $115.1 \pm 5.1$ & Srivastava et al (Comm. to Lithos) \\
\hline \multicolumn{4}{|l|}{ 2. Jasra } \\
\hline $\mathrm{U}-\mathrm{Pb}$ & $\begin{array}{l}\text { Zircon and baddeleyite from } \\
\text { differentiated gabbro }\end{array}$ & $105.2 \pm 0.5$ & Heaman et al (2002) \\
\hline \multicolumn{4}{|l|}{ 3. Samchampi } \\
\hline Fission track $\quad A$ & Apatite & $\sim 105$ & Acharya et al (1986) \\
\hline \multicolumn{4}{|c|}{ Lamprophyres from conjugate Indian and Antarctic margins } \\
\hline $\mathrm{K}-\mathrm{Ar} \quad \mathrm{I}$ & Lamprophyre dyke from Swangkre & $107 \pm 3$ & Sarkar et al (1996) \\
\hline Ar-Ar & $\begin{array}{l}\text { Biotite from lamprophyre dyke of } \\
\text { Indian margin }\end{array}$ & $114.9 \pm 0.3$ & Coffin et al (2002) \\
\hline Ar-Ar & $\begin{array}{l}\text { Biotite from lamprophyre dyke of } \\
\text { Antarctic margin }\end{array}$ & $114 \pm 0.3$ & \\
\hline
\end{tabular}

Naturaliste plateau, Rajmahal-Sylhet province, and several ultramafic-alkaline-carbonatite rocks of Shillong plateau (see table 3 for references). Many workers (Coffin et al 2002; Kent et al 2002 and references therein) have established that Kerguelen hotspot was active since $130 \mathrm{Ma}$ and is responsible for mafic and alkaline magmatism in the Shillong plateau. These authors have also presented the plate reconstruction of Indian Ocean and suggested that the Kerguelen hotspot was very close to the Shillong plateau between $100 \mathrm{Ma}$ and $115 \mathrm{Ma}$. This is consistent with the age data of these rocks (table 3). The spatial and temporal distribution of mafic and ultramafic-alkaline-carbonatite magmatism (table 3) clearly suggests their genetic link with the Kerguelen plume. Further, on the basis of age data of basalts from the Kerguelen plateau, Broken ridge, Naturaliste plateau, Bunbury, and Rajmahal-Sylhet Igneous province and plate reconstruction, Kent et al (2002) have stated that the eruption of the Rajmahal basalts and Elan's Bank separation from eastern India can be explained by interaction between the Kerguelen hotspot and a spreading ridge located close to the eastern India margin at $\sim 120 \mathrm{Ma}$.

\section{Conclusion}

The early Cretaceous mafic dykes associated with the N-S trending deep-seated Nongchram fault are emplaced in the Archaean gneissic complex of the Shillong plateau. These are well exposed around the Swangkre-Rongmil region and show very sharp contact with the country rocks. Although there are differences in petrography of the dyke margin samples (fine-grained basalt) and samples from the middle portion of dyke (medium-grained dolerite), their chemistry is consistent and show basaltic andesitic characteristics. No evidence of 

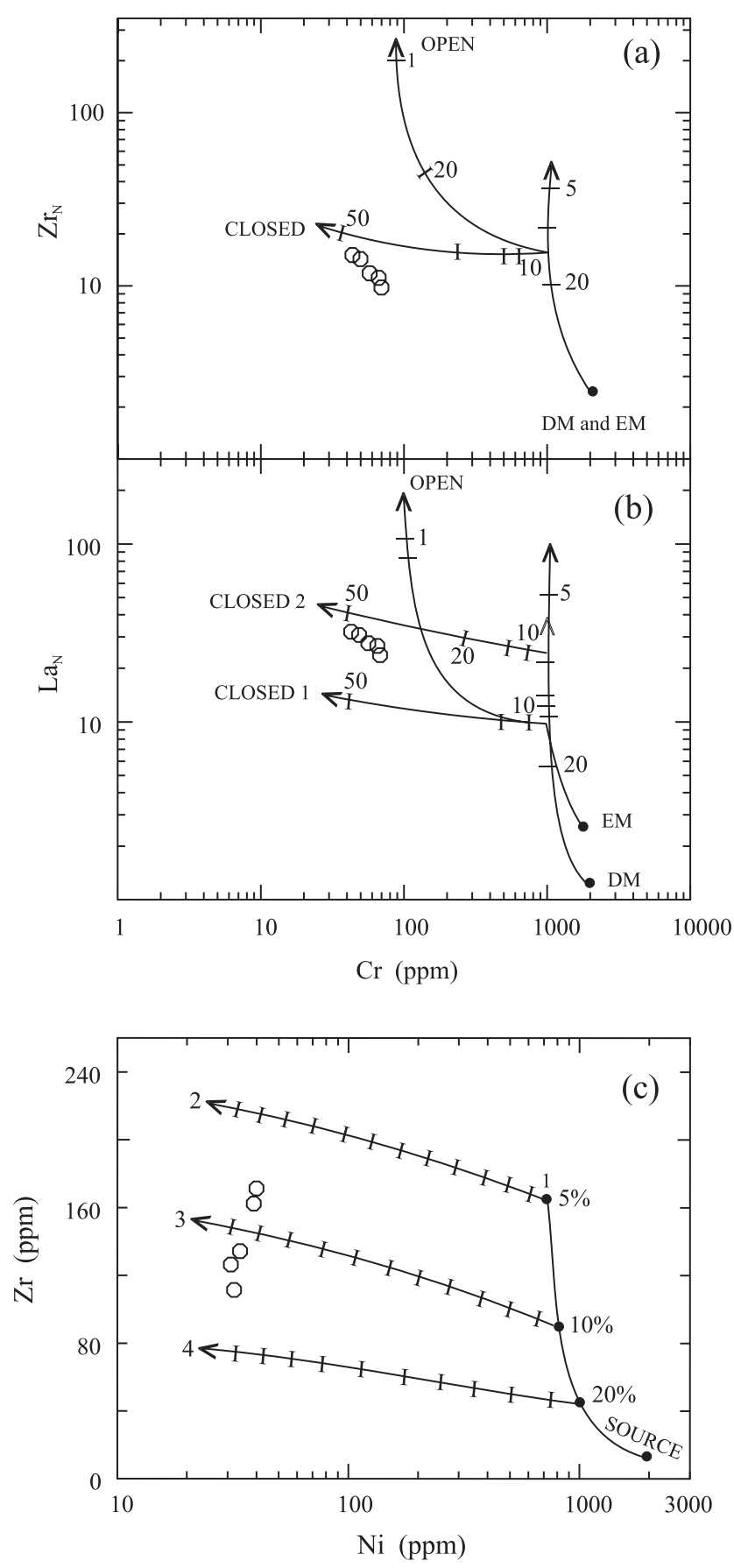

Figure 10. Petrogenetic model based on compatible ( $\mathrm{Cr}$ and $\mathrm{Ni}$ ) and incompatible ( $\mathrm{La}$ and $\mathrm{Zr}$ ) elements for the Swangkre-Rongmil mafic dyke samples. (a) and (b) Bulk silicate earth values for normalization $(\mathrm{La}=0.708 \mathrm{ppm}$; $\mathrm{Zr}=11.2 \mathrm{ppm})$ were taken from McDonough et al (1992). Enriched (EM) and depleted (DM) mantle sources are taken from Wood (1979). Batch melting curves and fractional crystallisation tick marks are adopted from Knoper and Condie (1988), which have been calculated assuming a lherzolite mantle source (source mode: ol, 0.60; opx, 0.15, cpx, 0.25; melting mode: ol, 0.25 ; opx, 0.55 ; cpx, 0.20); the corresponding D values used by Knoper and Condie (1988) were not explicitly reported by these authors although they stated that these values could be obtained from them. Closed system fractionation curves were calculated beginning with $15 \%$ batch melts with tick marks, indicating degree of fractional crystallization. Open system fractionation curves are also calculated from $15 \%$ batch melt with degree of fractional crystallization held constant at 50\%, and tick marks indicate leakage from a replenished and tapped magma chamber (after O'Hara 1977). (c) Petrogenetic model based on $\mathrm{Zr}$ and $\mathrm{Ni}$ (after Condie et al 1987). (1) Batch melting curve at $1500^{\circ} \mathrm{C}$ (1 atm equivalent) with degrees of melting noted in per cent. Melting relation of assumed lherzolite mantle source (11 ppm $\mathrm{Zr}$ and $2000 \mathrm{ppm} \mathrm{Ni}$ ) is as given by Rajamani et al (1985); (2, 3 and 4): olivine fractionation curves with per cent of olivine removal noted in $5 \%$ increments.

assimilation between the mafic dyke and the country rock is noticed in the field. Field evidence and chemistry do not support any severe contamination by crust. But, on the other hand, geochemical similarities noticed between the present samples, the Elan Bank basalts, and the Rajmahal (Group II) mafic dyke samples suggest involvement of upper crust before emplacement of these rocks. $\mathrm{Nb} / \mathrm{La}, \mathrm{La} / \mathrm{Ta}$, and $\mathrm{Ba} / \mathrm{Ta}$ ratios also support this view. The chemistry of these mafic dyke samples also suggests their genetic relationship with each other. Trace element modelling indicates that these mafic rocks were derived from a melt generated by $\sim 10-15 \%$ melting of a deep mantle source (probably lherzolite) and that has been emplaced in the region after $>50 \%$ differentiation of an alkaline basaltic magma. The cause of the melting of a mantle is probably the Kerguelen mantle plume. Thus, on the basis of spatial and temporal association of mafic dykes of the present study with the mafic and alkaline-carbonatite magmatism of the Shillong plateau and close association with the lamprophyre dykes of the region, it is believed that these dykes also have genetic relationship with the Kerguelen mantle plume.

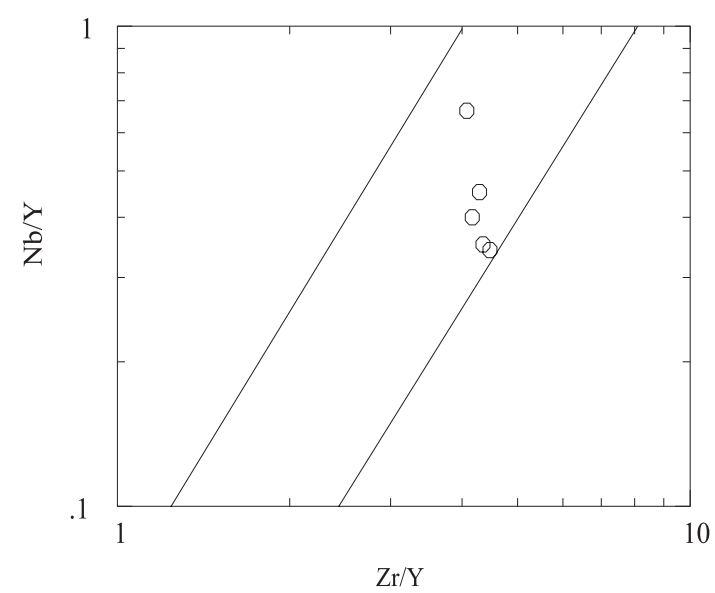

Figure 11. $\mathrm{Zr} / \mathrm{Y}$ and $\mathrm{Nb} / \mathrm{Y}$ variation in the SwangkreRongmil mafic dyke samples. Samples fall between the parallel lines display deep-mantle (plume) signature (Fitton et al 1997; Baksi 2000). 


\section{Acknowledgements}

The authors are grateful to Hetu Sheth for inviting them to write a paper for this special volume. They are thankful to Ray Kent, Dominique Weis, and an anonymous reviewer for their constructive comments and suggestions for improving the manuscript. RKS is thankful to UGC, New Delhi for providing financial assistance for this work [Scheme No. F. 5-21/2001 (SR-I)]. The authors are thankful to S Kanjilal for correcting linguistic mistakes in the manuscript.

\section{References}

Acharya S K, Mitra N D and Nandy D R 1986 Regional geology and tectonic setting of north east India and adjoining region; Geol. Surv. India 119 6-12

Baksi A K 1995 Petrogenesis and timing of volcanism in the Rajmahal flood basalt province, Northeastern India; Chem. Geol. 121 73-90

Baksi A K 2000 Search for a deep-mantle component in mafic lavas using Nb-Y-Zr plot; Canadian J. Earth Sci. 38 813-824

Baksi A K, Barman T R, Paul D K and Farrar E 1987 Widespread Early Cretaceous flood basalt volcanism in eastern India: geochemical data from the RajmahalBengal-Sylhet traps; Chem. Geol. 63 133-141

Baragar W R A, Ernst R E, Hulbert L and Peterson T 1996 Longitudinal petrochemical variation in the Mackenzie dyke swarm, Northwestern Canadian Shield; J. Petrol. 37 317-359

Cadman A C, Tarney J, Bridgewater D, Mengel F, Whitehouse M J and Windley B F 2001 The petrogenesis of the Kangâmiut dyke swarm, W. Greenland; Precam. Res. $105183-203$

Coffin M F, Pringle M S, Duncan R A, Gladezenko T P, Storey M, Müller R D and Gahagan L A 2002 Kerguelen hotspot magma output since $130 \mathrm{Ma}$; J. Petrol. 43 $1121-1139$

Condie K C, Bobrow D J, Card K D 1987. Geochemistry of Precambrian mafic dykes from the southern Superior province of the Canadian shield. In: Mafic Dyke Swarms (eds) H C Halls and W F Fahrig (Canada: Geol. Assoc.) Spl. Pap. 34 pp. $95-108$

Cullers R L and Graf J L 1984 Rare earth elements in igneous rocks of the continental crust: predominantly basic and ultrabasic rocks. In: Rare Earth Element Geochemistry (ed) Henderson P (Amsterdam: Elsevier) pp. $237-274$

Das Gupta A B and Biswas A K 2000 Geology of Assam. (Bangalore, India: Geol. Soc.) 169p

Desikachar S V 1974 A review of the tectonic and geological history of eastern India in terms of plate tectonic theory; J. Geol. Soc. India 15 137-149

Duncan R A 2002 A time frame for construction of the Kerguelen Plateau and Broken Ridge; J. Petrol. 43 1109-1119

Evans P 1964 The tectonic framework of Assam; J. Geol. Soc. India 5 80-96

Evensen N M, Hamilton P J and O'Nion R K 1978 Rare earth abundances in chondritic meteorites; Geochim. Cosmoch. Acta 42 1199-1212

Fahrig W F 1987 The tectonic settings of continental mafic dyke swarms: failed arm and early passive margin. In:
Mafic Dyke Swarms (eds) H C Halls and W F Fahrig (Canada: Geol. Assoc.) Spl. Pap. 34 pp. 331-348

Fitton J G, Saunders A D, Norry M J, Hardarson B S and Taylor R N 1997 Thermal and chemical structure of the Iceland plume; Earth Planet. Sci. Lett. 153 197-208

Frey F A, McNaughton N J, Nelson D R, deLaeter J R and Duncan R A 1996 Petrogenesis of the Bunbury basalt, Western Australia: interaction between the Kerguelen plume and Gondwana lithosphere? Earth Planet. Sci. Lett. 176 73-89

Ghosh S, Chakrabarty S, Paul D K, Bhalla J K, Bishui P K and Gupta S N 1994 New Rb-Sr isotopic ages and geochemistry of granitoids from Meghalaya and their significance in middle to late Proterozoic crustal evolution; Indian Minerals 48 33-44

Golani P R 1991 Nongchram fault: A major dislocation zone from western Meghalaya; J. Geol. Soc. India 12 $56-62$

Gupta R P and Sen A K 1988 Imprints of Ninety-East Ridge in the Shillong Plateau, Indian Shield; Tectonophysics $154335-341$

Heaman L M, Srivastava R K and Sinha A K 2002 A precise $\mathrm{U}-\mathrm{Pb}$ zircon/baddeleyite age for the Jasra igneous complex, Karb-Analong district, Assam, NE India; Curr. Sci. $82744-748$

Ingle S, Weis D, Scoates J S and Frey F A 2002 Relationship between the early Kerguelen plume and continental flood basalts of the paleo-Eastern Gondwana marigins; Earth Planet. Sci. Lett. 197 35-50

Irvine T N and Baragar W R A 1971 A guide to the chemical classification of the common volcanic rocks; Canadian J. Earth Sci. 8 523-548

Jochum K P and Verma S P 1996 Extreme enrichment of $\mathrm{Sb}, \mathrm{Tl}$, and other trace elements in altered MORB; Chem. Geol. 130 289-299

Kent R W, Saunders A D, Kempton P D and Ghose N C 1997 Rajmahal basalts, eastern India: mantle source and melt distribution at a volcanic rifted margin. In: Large Igneous Provinces - Continental, Oceanic and Planetary Flood Volcanism (eds) J J Mahoney and M F Coffin Geophysical Monograph 100 pp. 145-182

Kent R W, Pringle M S, Müller R D, Saunders A W and Ghose N C $2002{ }^{40} \mathrm{Ar} /{ }^{39} \mathrm{Ar}$ geochronology of the Rajmahal basalts, India, and their relationship to the Kerguelen Plateau; J. Petrol. 43 1141-1153

Knoper M W and Condie K C 1988 Geochemistry and petrogenesis of Early Proterozoic amphibolites, West-Central Colorado, U.S.A.; Chem. Geol. 67 209-225

Kumar D, Mamallan R and Diwedy K K 1996 Carbonatite magmatism in northeast India; J. Southeast Asian Earth Sci. 13 145-158

LeCheminant A N and Heaman L M 1989 Mackenzie igneous events, Canada, middle Proterozoic hotspot magmatism associated with ocean opening; Earth Planet. Sci. Lett. $9638-48$

Le Maitre R W 2002 Igneous Rocks: A classification and glossary of terms; (Cambridge: Cambridge University Press) $236 \mathrm{p}$

Mahoney J J, Jones W B, Frey F A, Salters V J M, Pyle D G and Davies H L 1995 Geochemical characteristics of lavas from Broken Ridge, the Naturaliste Plateau and southernmost Kerguelen Plateau: Cretaceous plateau volcanism in the southeast Indian Ocean; Chem. Geol. 120 315-345

Mazumdar S K 1976 A summary of the Precambrian geology of the Khasi Hills, Meghalaya; Geol. Surv. India Miscell. Publ. 23(2) 311-334

McDonough W F, Sun S S, Ringwood A E, Jagoutz E and Hofmann A W $1992 \mathrm{~K}, \mathrm{Rb}$ and Cs in the earth and moon 
and the evolution of the earth's mantle; Geochim. Cosmoch. Acta 56 1001-1012

Middlemost E A K 1989 Iron oxidation ratios, norms and the classification of volcanic rocks; Chem. Geol. 77 19-26

Morgan W J 1971 Convection plumes in the lower mantle; Nature $23042-43$

Murthy N G K 1987 Mafic dyke swarms of the Indian Shield. In: Mafic Dyke Swarms (eds) H C Halls and W F Fahrig (Canada: Geol. Assoc.) Spl. Pap. 34 pp. 393-400

Nambiar A R 1987 Alkaline magmatism in parts of East Garo Hills and West Khasi Hills districts, Meghalaya; Rec. Geol. Surv. India 115 25-41

Nambiar A R 1988 Petrology of lamprophyres from parts of East Garo Hills and West Khasi Hills districts, Meghalaya; J. Geol. Soc. India 32 125-136

Nambiar A R and Golani P R 1985 A new find of carbonatite from Meghalaya; Curr. Sci. 54 281-282

Nandy D R 1980 Tectonic pattern in north eastern India; Indian J. Earth Sci. 7 103-107

O'Hara M J 1977 Geochemical evolution during fractional crystallization of a periodically filled magma chamber; Nature 265 503-507

Oliveira E P, Tarney J and Joao X J 1990 Geochemistry of Mesozoic Amapa and Jari dyke swarms, northern Brazil: plume-related magmatism during the opening of the central Atlantic. In: Mafic Dykes and Emplacement Mechanism (eds) A J Parker, P C Rickwood and D H Tucker (Rotterdam: A A Blakema) pp. 173-183

Pearce J A and Cann J R 1971 Ophiolite origin investigated by discriminant analysis using $\mathrm{Ti}, \mathrm{Zr}$ and $\mathrm{Y}$; Earth Planet. Sci. Lett. 12 339-349

Pearce J A and Cann J R 1973 Tectonic setting of basic volcanic rocks determined using trace element analysis; Earth Planet. Sci. Lett. 19 290-300

Pyle D G, Christie D M, Mahoney J J and Duncan R A 1995 Geochemistry and geochronology of ancient southeast Indian Ocean and southwest Pacific Ocean seafloor; J. Geophy. Res. B100 22261-22282

Rajamani V, Shivkumar K, Hanson G N and Shirey S B 1985 Geochemistry and petrogenesis of amphibolites, Kolar schist belt, South India: evidence for komatiitic magma derived by low percentage of melting of the mantle; J. Petrol. 26 92-123

Ray J S, Ramesh R and Pande K 1999 Carbon isotopes in Kerguelen plume-derived carbonatites: evidence for recycled inorganic carbon; Earth Planet. Sci. Lett. 170 205-214

Ray J S, Trivedi J R and Dayal A M 2000 Strontium isotope systematics of Amba Dongar and Sung Valley carbonatite-alkaline complexes, India: evidence for liquid immiscibility, crustal contamination and long-lived $\mathrm{Rb} / \mathrm{Sr}$ enriched mantle source; J. Asian Earth Sci. 18 585-594

Salters V J M, Storey M, Sevigny J H and Whitechurch H 1992 Trace element and isotopic characteristics of
Kerguelen-Heard plateau basalts; Proc. Ocean Drilling Prog., Scientific Results 120 55-62

Sarkar A, Datta A K, Poddar B K, Bhattacharyya B K, Kollapuri V K and Sanwal R 1996 Geochronological studies of Mesozoic igneous rocks from eastern India; J. Southeast Asian Earth Sci. 13 77-81

Srivastava R K and Sinha A K 2004a The Early Cretaceous Sung Valley ultramafic-alkaline-carbonatite complex, Shillong Plateau, Northeastern India: petrological and genetic significance; Mineral. Pet. 80 241-263

Srivastava R K and Sinha A K 2004b Geochemistry of Early Cretaceous Alkaline Ultramafic-Mafic Complex from Jasra, Karbi Anglong, Shillong Plateau, Northeastern India; Gondwana Res. 7 549-561

Storey M, Kent R W, Saunders A D, Hergt J, Salters V J M, Whitechurch H, Sevigny J H, Thirlwall M F, Leat P, Ghose N C and Gifford M 1992 Lower Cretaceous volcanic rocks on continental margins and their relationship to the Kerguelen Plateau; Proc. Ocean Drilling Prog., Scientific Results 120 33-53

Sunilkumar, Dhanaraju R, Varma H M and Dougall N K 1984 Cancrinite-tinguatite and K-rich trachyte in Nongchram-Darugiri area of East Garo Hills district, Meghalaya: a preliminary study; J. Geol. Soc. India 25 $528-533$

Tarney J 1992 Geochemistry and significance of mafic dyke swarms in the Proterozoic; In: Proterozoic Crustal Evolution (ed) K C Condie Elsevier, New York, pp. $151-179$

Tarney J and Weaver B L 1987 Geochemistry and petrogenesis of early Proterozoic dyke swarms. In: Mafic Dyke Swarms (eds) H C Halls and W F Fahrig (Canada: Geol. Assoc.) Spl. Pap. 34 pp. 81-94

Thompson R N 1984 Dispatches from the basalt front: 1 . Experiments; Proc. Geol. Assoc. 95 249-262

Thompson R N and Gibson S A 1991 Sub-continental mantle plumes, hotspots, and pre-existing thinspots; J. Geol. Soc. London 148 973-977

Verma S P 1992 Seawater alteration effects on REE, K, Rb, $\mathrm{Cs}, \mathrm{Sr}, \mathrm{U}, \mathrm{Th}, \mathrm{Pb}$, and $\mathrm{Sr}-\mathrm{Nd}-\mathrm{Pb}$ isotope systematics of mid-ocean ridge basalts; Geochem. J. 26 159-177

Verma S P, Torres-Alvarado I S, and Sotelo-Rodríguez Z T 2002 SINCLAS: standard igneous norm and volcanic rock classification system; Computers $\&$ Geosciences $\mathbf{2 8}$ 711-715

Weaver B L and Tarney J 1984 Estimating the composition of the continental crust: an empirical approach; Nature $310575-577$

Winchester J A and Floyd P A 1977 Geochemical discrimination of different magma series and their differentiation products using immobile elements; Chem. Geol. 20 325-344

Wood D A 1979 A variably veined suboceanic upper mantle: genetic significance for mid-ocean ridge basalts from geochemical evidence; Geology 7 499-503 